\title{
Diurnal Activity Budget and Habitat Usage of Four Ciconiiformes Species at the Annaiwilundawa Ramsar Wetland Sanctuary, Sri Lanka
}

Karunarathne G.D.N.S. ${ }^{*}$ and Mahaulpatha W.A.D.

\author{
Department of Zoology, Faculty of Applied Sciences, University of Sri Jayewardenepura, Nugegoda, \\ Sri Lanka \\ *nisansalakarunarathne@yahoo.com
}

\begin{abstract}
Annaiwilundawa Ramsar wetland provides suitable habitats for a large number of resident and migratory bird species. Ciconiiformes of the Annaiwilundawa Ramsar wetland forms a discernible component and hence have been identified as a potential bio-indicator group. Present study recorded the diurnal activity budgets of four Ciconiiformes species, namely Purple Heron (Ardea purpurea), Intermediate Egret (Ardeola grayii), Indian Pond Heron (Egretta garzetta) and Little Egret (Mesophoyx intermedia) at the Annaiwilundawa Ramsar wetland once a month from December 2011 to November 2012.
\end{abstract}

The day was divided in to three time periods as morning (6.15-10.15 hrs), noon (10.15-2.15 hrs) and evening (2.15-6.15 hrs). Activities of the birds were categorized as feeding, locomotion, resting, preening, alert and searching. The activity of the birds and the habitat in which the activity occurred was recorded using focal and scan sampling methods in each time period. Each bird species was observed for 30 minutes in each time period and the location of the observed bird species was recorded on a 1:50,000 scale topographical map of the Annaiwilundawa. The marked points were jointed to conclude the 'Used Area' of the relevant species.

All four species had significant difference in the diurnal activity budgets in each time period. Resting was the most dominant behaviour of these four species \{[Purple Heron $=57.83 \pm 18.54 \%$ ], [Indian Pond Heron=35.42 $\pm 2.63 \%$ ], [Little Egret $=34.11 \pm 3.16 \%$ ] and [Intermediate Egret $=40.12 \pm 12.56 \%$ ] $\}$. Size of the area used by the four Ciconiiformes species did not differ significantly (ANOVA, $F=2.064, \mathrm{P} \geq 0.1110$ ). However, they showed significant relationships between percentage time spent in different habitats and there availability within the 'Used Area' (Spearman correlation, Purple Heron $\mathrm{z}=3.258, \mathrm{P} \leq 0.0011$; Indian Pond Heron $\mathrm{z}=3.087, \mathrm{P} \leq$ 0.0020; Little Egret $\mathrm{z}=1.978, \mathrm{P} \leq 0.0480$; Intermediate Egret $\mathrm{z}=3.335$, $\mathrm{P} \leq 0.0008$ ). Present study indicated that these four species of Ciconiiformes used the Annaiwilundawa reservoir primarily for resting. Clear habitat partition and area usage was observed which may have allowed these four species to co-exist sympatrically at the Annaiwilundawa Ramsar wetland.

Keywords: Diurnal activity budget, Annaiwilundawa, Habitat utilisation, Habitat availability 